\title{
Revaluation of Maturity and Stability Indices for Compost
}

\author{
SARWOKO MANGKOEDIHARDJO \\ Laboratory of Environmental Technology and Process Engineering, \\ Department of Environmental Engineering, Institut Teknologi Sepuluh Nopember (ITS), \\ Jalan AR Hakim Sukolilo, Surabaya 60111, Indonesia,
}

\begin{abstract}
BOD} / \mathrm{COD}$ ratio of compost was studied in conjunction with $\mathrm{C} / \mathrm{N}$ ratio as commonly maturity index. Carbonaceous materials as well as nitrogenous materials declined in open-air conditions during 20 weeks. $\mathrm{C} / \mathrm{N}$ ratio was correlated with $\mathrm{BOD} / \mathrm{COD}$, a couple parameters to qualify the compost was mature and stable. This study came up to the conclusion that compost maturity with $\mathrm{C} / \mathrm{N}$ of less than 14 instead of less than 20 was corresponding to stability with BOD/COD of less than 0.1 . Additional assurance on maturity and stability was carbon dioxide emission rate of less than $2 \mathrm{mg}$ C/g VS/day.@JASEM
\end{abstract}

Composting is an exothermic aerobic biological process that stabilizes biodegradable organic matter (BOM). Decomposition rates are affected by all factors that commonly affect microbial growth, i.e. carbon, nitrogen, oxygen, moisture, $\mathrm{pH}$, temperature, and nutrient levels. A composting process occurs until all BOM is stabilized that is odor and pathogen free, and a poor breeding substrate for flies and other insects. Even the compost has been stable care should be taken for application to soil for crop use because the biological processes will continue and can rob the nutrients of soil. A measure of compost that is conducive for crop growth refers to maturity (Wang et al, 2004), representing relationship between compost quality and crop growth. On the other hand stability refers to the aerobic biological activity (Llewelyn, 2005), representing relationship between compost quality and biological activity within the compost. An important parameter for compost maturity is the carbon to nitrogen ratio $(\mathrm{C} / \mathrm{N}) . \mathrm{C} / \mathrm{N}$ of less than 20 is common throughout the international composting industry as an indication of maturity. So far, it is not part of regulations but forms part of guidelines administered by Ministry of Environment and provinces in Indonesia. In addition to $\mathrm{C} / \mathrm{N}$ ratio, recommendation has been proposed to include oxygen uptake rate (OUR) for stability parameter. However, this study was to consider another parameter of compost stability, which is biological oxygen demand (BOD) to chemical oxygen demand (COD) ratio. The low $\mathrm{BOD} / \mathrm{COD}$ ratio may indicate the presence either of organic matter that are hard to biodegrade, meaning microbiologically stable, or it may be due to the presence of toxic organics inhibiting the microbial activities. The inclusion of multiple standards for maturity and stability of compost will increase the compost quality testing accuracy. Concerns on these compost quality standards, therefore the specific objective of this study was to revaluate $\mathrm{C} / \mathrm{N}$ ratio in conjunction with BOD/COD ratio.

\section{MATERIALS AND METHODS}

Composts were collected from three of the sites visited in the provinces of Banten, Jakarta, and West Java, Indonesia. These sites used municipal solid waste as a feedstock for compost production. All three samples were collected from compost maturation bed at the first day they were put in. Three replicates experiment were organized. All three samples were divided into three piles, each was weighted 100 kilograms. The $20 \mathrm{~mm}$ screened test composts were each thoroughly homogenized. The test composts arranged as windrow piles to simulate the existing maturation bed. This study was run for 20 weeks period of stabilization during which the compost quality measurements for each pile were carried out every week.

Each of compost samples was examined for bulk density, wet weight (WW), dry weight (DW), and volatile solids (VS) with reference to Standard Methods (1995). Bulk density was measured similar to WW in $1 \mathrm{~L}$ of volumetric flask using Archimedes principles i.e. measuring volume of water replacement following addition of a known weight of sample. Substracting DW from WW was used to calculate moisture content in addition to the fist test (Llewelyn, 2005). It should be noted that moisture content was maintained about $45-60 \%(\mathrm{w} / \mathrm{w})$ for all composts by adding tap water, unless the initial content was higher than that. The total nitrogen (organic and inorganic forms) as $\mathrm{N}$ was measured in water extractable substances. One $\mathrm{L}$ of hot distillate water was added into 100 grams of each sample and shake for 24 hours in shaker. Komilis and Ham (2000) used hot water extraction in order to extract sugars, amino acids, starch and pectins, which all are BOM-containing compost. An aliquot of each was examined for total kjeldahl nitrogen (TKN), ion ammonia $\left(\mathrm{NH}^{+}\right)$, nitrate $\left(\mathrm{NO}^{-}\right)$, nitrite $\left(\mathrm{NO}^{-}\right)$, temperature, $\mathrm{pH}$, dissolved oxygen (DO), BOD, and COD. Laboratory works for all analytical measurements were in accordance with Standard Methods (1995).

*Corresponding author: Phone +62315948886, Fax +62315928387 ,

Email: sarwoko@enviro.its.ac.id 
Total organic carbon as $\mathrm{C}$ was measured as carbon dioxide emmisions during 4 days following equilibration period of 3 days at $30{ }^{\circ} \mathrm{C}$ incubation. Carbon dioxide entrapment solution was sodium hydroxide; the collected sodium carbonate is precipitated as barium carbonate by the addition of excess barium chloride. The concentration of carbon dioxide evolved by the compost is measured by titration of the residual sodium hydroxide with standard acid using phenolphthalein indicator. The complete description of the test method was provided by Llewelyn (2005).

\section{RESULTS AND DISCUSSION}

Primary composting process parameters were applied for evaluation of compost stabilization process. During 20 weeks period the parameters observed were as follows. Compost temperatures were ranging from $25{ }^{\circ} \mathrm{C}$ and $30^{\circ} \mathrm{C}$, however, these were influenced by room temperature fluctuation, suggesting the composts were proceed in approaching stabilization stage. Moisture content of compost was $51 \% \pm 6 \%$. Observation on DO showed that it was ranging from $5.6 \mathrm{mg} / \mathrm{L}$ to 6.2 $\mathrm{mg} / \mathrm{L}$. Declining of $\mathrm{pH}$ was observed from 8.1 to 7.8 .
Those parameters were not limiting to ensure the microbes alive and well active to stabilize the compost. The aerobic condition brought about respiration of BOM-containing compost, as a result, the BOM measured as BOD and COD would be decreased. This study showed that decreasing of COD was slower than decreasing of BOD, representing $\mathrm{BOD} / \mathrm{COD}$ ratio tended to approach zero. Decreasing of BOD/COD ratio was meant that the compost became non-biodegradable, or stable in terms of no further biodegradation. As long as the BOM content as BOD and COD were decreased, this resulted in decreasing emission of carbon dioxide, suggesting the compost undergone stabilization. The time profile of compost stability (Fig. 1) could be divided into 3 stages, i.e. stage 1 (compost age between 0 and 6 weeks), stage 2 (6 weeks to 12 weeks), and stage 3 (after 12 weeks) which were classified as active degradation, intermediate, and stability period respectively. The compost would be stable after 12 weeks by indicating quantitative carbon dioxide emission rate of $2 \mathrm{mg} \mathrm{C} / \mathrm{g} \mathrm{VS} /$ day. This result was similar to Llewelyn (2005) in his work with compost stability classification and he suggested stable compost was less than $8 \mathrm{mg} \mathrm{CO} 2 / \mathrm{g} \mathrm{VS} /$ day after 14 weeks.

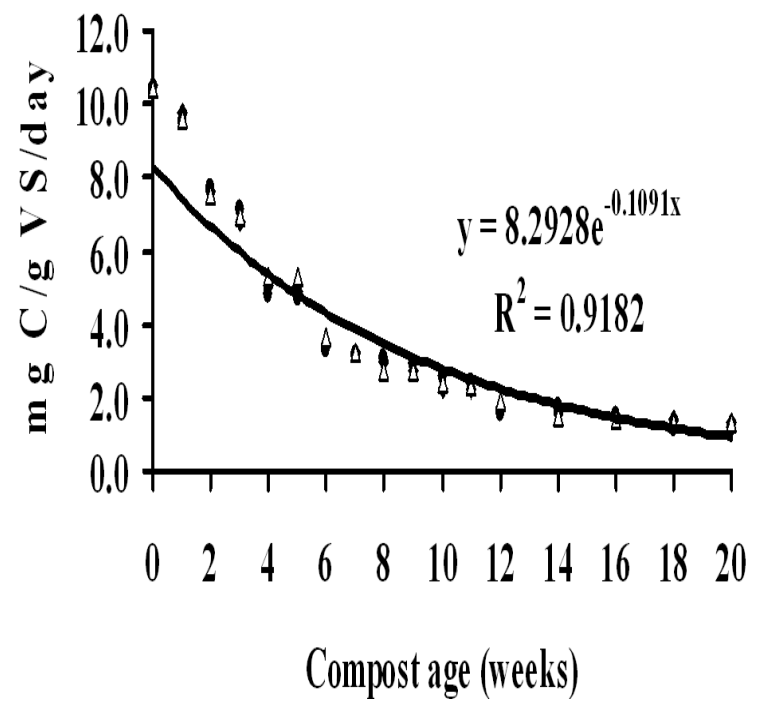

Fig 1. Time profile for composite stability

In addition to aerobic environment, an alkaline condition brought about inorganic ammonia forms were generated from protein and urea hydrolysis. With a pH over 8.0, ammonia increases exponentially with each small rise in $\mathrm{pH}$ (Wang et al, 2004). This study reports that all inorganic nitrogen forms were decreased. Organic nitrogen sources were measured as TKN which was shown to decrease from $0.7 \mathrm{mg} \mathrm{N} / \mathrm{g}$ VS to $0.3 \mathrm{mg} \mathrm{N} / \mathrm{g}$ VS. In this condition much of volatile $\mathrm{NH} 3$, which can be fairly noxious and potentially plant toxic was converted to $\mathrm{NH}^{+}$. Ion ammonium was observed to decrease from $0.6 \mathrm{mg} \mathrm{N} / \mathrm{g} \mathrm{VS}$ to $0.2 \mathrm{mg} \mathrm{N} / \mathrm{g} \mathrm{VS}$, however, nitrification did occur producing nitrogen species $\mathrm{NO}^{-}$and $\mathrm{NO}^{-}$. The nitrite and nitrate content were about $0.1 \mathrm{mg} \mathrm{N} / \mathrm{g}$ VS and $0.2 \mathrm{mg} \mathrm{N} / \mathrm{g}$ VS respectively, and both were disappeared after 5 weeks. Therefore the decreasing of inorganic nitrogen was not due to small drop in $\mathrm{pH}$, but was as a result of immobilization by the nitrifiers in conjunction with decreasing of DO. The total organic nitrogen and inorganic nitrogen species were taken into account for the total N. Therefore during compost stabilization suggested that there was no nitrogen limiting conditions for protein synthesis by the indigenous microbes while consuming organic carbon-containing BOM in the compost as an energy source. 


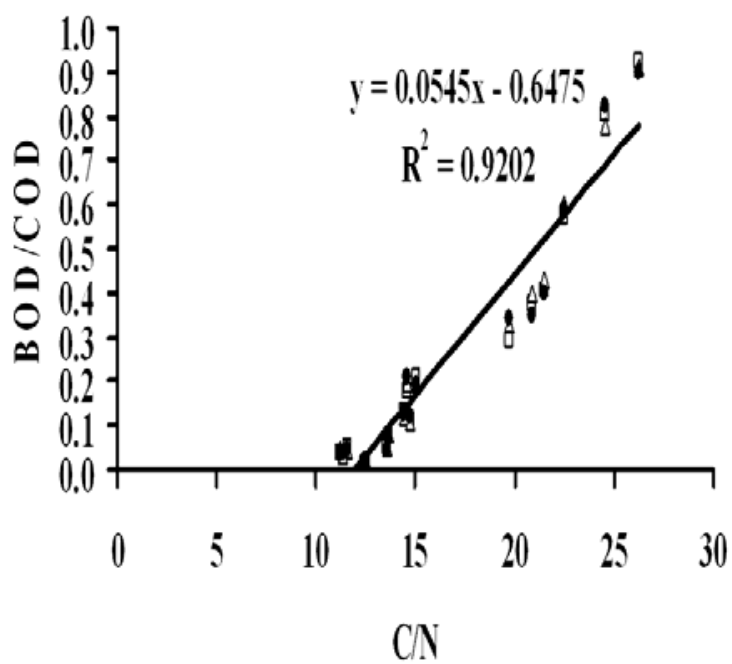

Fig 2. Correlation between $\mathrm{BOD} / \mathrm{COD}$ and $\mathrm{C} / \mathrm{N}$

Since BOD, COD, C, and N were declined, this came up to the relationship between $\mathrm{BOD} / \mathrm{COD}$ and $\mathrm{C} / \mathrm{N}$ (Fig. 2 ). The correlation of both represents a positive correlation between aqueous carbon contents and carbon dioxide production, which was observed by Komilis (2006). Since BOD and COD measure the soluble $\mathrm{BOM}$ of compost and $\mathrm{BOD} / \mathrm{COD}$ ratio indicates the extent of compost degradation by microbes, therefore a limit of compost stability should be determined. In agreement with the stability BOD/COD ratio of less than 0.1 (Borglin et al., 2004), the value of 0.1 was considered as the maximum limit for compost stability. This compares favorably with the values obtained by Krzystek et al. (2003) in their work with the stabilization rate of leachate biotreatment, and Guan et al. (2004) in their work with the COD removal of wastes. Accordingly, and using the result obtained in Fig. 2 it follows that one may calculate the maximum $\mathrm{C} / \mathrm{N}$ ratio was 14 as a maturity parameter.

Acknowledgement: The author wishes to thanks the project manager of Western Java Environment Management Programme and the sub project manager of composting subsidy programme at the Ministry of Environment for supporting facilities their provided.

\section{REFERENCES}

Borglin, S E; Hazen, TC; Oldenburg, CM (2004). Comparison of aerobic and anaerobic biotreatment of municipal solid waste. Air \& Waste Manage Assoc 54: 815-822.

Guan B; Wu Z; Xu, G (2004). Kinetics of aerobically activated sludge on terylene artificial silk printing and dyeing wastewater treatment. J Zhejiang Univ SCI 5(4): 441-449.

Komilis, D P (2006). A kinetic analysis of solid waste composting at optimal conditions. Waste Manage 26: $82-91$

Komilis, D P; Ham, R K (2000). A laboratory method to investigate gaseous emissions and solids decomposition during composting of municipal solid waste. Compost Sci Util 8, 254-265.

Krzystek, L; Zieleniewska, A; Ledakowicz, S; Kahle, H J (2003). Simulation of aerobic stabilization of municipal landfills in lysimeters. EJ Polish Agric Univ Biotech 6(2): 11 p.

Llewelyn, R H (2005). Development of standard laboratory based test to measure compost stability. The Waste \& Resources Action Programme The Old Academy, 21 Horse Fair, Banbury, Oxon OX16 0AH.

Standard Methods (1995). Standard Methods for the Examination of Water and Wastewater. American Public Health Association/American Water Works Association/Water Environmental Federation, Washington DC, 19th Ed.

Wang, P; Changa C M; Watson M E; Dick W A; Chen Y; Hoitink H A J (2004). Maturity indices for composted dairy and pig manures. Soil Biol Biochem 36: 767-776. 